\title{
Reflections on shifts in the work identity of research team members
}

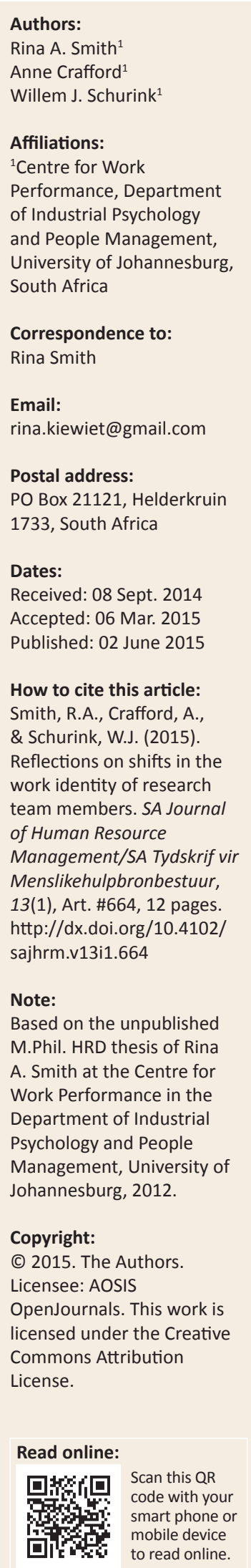

\section{Authors:}

Affiliations:

of Industrial Psychology

and People Management,

University of Johannesburg,

South Africa

Correspondence to:

Email:

PO Box 21121, Helderkruin

Dates:

Received: 08 Sept. 2014

Accepted: 06 Mar. 2015

work identity of research

Management/SA Tydskrif vir

Menslikehulpbronbestuur

htt//dx.doi.org/10.4102/

Note:

Based on the unpub A. Smith Work Performance in the Department of Industria

Psychology and People Management, University of

Copyright:

(C) 2015. The Authors. Licensee: AOSIS Commons Attribution License. to read onlin
Orientation: This study explores shifts in the work identity of individual members of a research team

Research purpose: The aim of the study is to explore shifts in work identity experienced by individual research team members during a project wherein they were studying work identity themselves.

Motivation for the study: This study seized the opportunity to do research on the shifts in work identify experienced by researchers whilst they were studying work identify as part of the South African-Netherlands Project for Alternatives in Development. This allowed the researcher the rather novel opportunity of conducting research on researchers and resulted in the project as a whole occurring at a dual level of analysis.

Research approach, design and method: Using thematic analysis methodology in the context of qualitative field research, 10 semi-structured interviews were conducted with five participants, all of them part of the research team who were themselves involved in conducting research on work identity. The sixth member of the research team, who is also one of the authors of this article, presented data related to shifts in her own work identity in her dissertation as an autoethnographic account. For purposes of this article, she is referred to as Participant 6 . Given the multiple research team members, each one of whom constituted an individual case, the researcher made use of a multiple case study approach whilst focusing on the intrinsic case. The holistic nature of description found in the case study involved every aspect of the lives of the research team members. Analysis was done by means of content analysis.

Main findings: In exploring the shifts in work identity experienced by individual research team members, it was discovered that finding meaning and purpose in the professional activities participants engaged in was of critical importance. Contextual realities and the way in which individuals approached the possibility of shifts also seemed to play a significant role. Both these aspects influenced the possibility of engagement with new peer groups, contacts and role models to explore various aspects of self in order to make a transition or shift. The findings lastly emphasised work identity as fluid and as entailing an element of performance. Irrespective of their life and career stage, all participants were engaged in processing possible selves.

Practical/managerial implications: This study has implications for organisations looking to improve productivity through an understanding of work identity. The broader project originated from the premise that work is central to building individual identity and is influenced by job and individual characteristics. It is proposed that these factors could influence work performance and, accordingly, impact on organisational performance.

Theoretical contribution: An application for shifts in work identity is done by positioning such shifts in a framework proposed by Ibarra. The study confirms that the proposed framework is suitable for application to shifts in work identity.

\section{Introduction}

\section{Reflections on shifts in the work identity of research team members}

This particular study formed part of a research project that was done under the auspices of the South African-Netherlands Project for Alternatives in Development (SANPAD) in conjunction with the Centre for Work Performance at the University of Johannesburg and the Vrije Universiteit, Amsterdam.

All SANPAD participants had to research predetermined topics and had to work within the parameters of the main research question of the broader project, namely: How does an individual's work identity evolve, establish and stabilise considering the effects of different contextual factors as well as different strategies and tactics? (SANPAD, 2006). 
The SANPAD project involved a four-phase approach. Phase 1 involved planning, conceptualising and operationalising aspects of the project as well as recruitment of students and capacity workshops to equip students. Phase 2 involved the qualitative phase of the project, which included planning workshops between students and study leaders as well as a field trip to the manufacturing company in preparation for the interviews that followed. All students participated in conducting in-depth interviews at the manufacturing company. Preliminary results were reported at a workshop at the Vrije Universiteit, Amsterdam, and at the Society for Industrial and Organisational Psychology Conference (SIOPSA) of 2008. Phase 3 involved the quantitative phase of the project by the two $\mathrm{PhD}$ students applying results gathered at the manufacturing company to conduct a survey at a telecommunications company. Phase 4 involved the dissemination of results by means of publications and seminars: the European Association of Work and Organizational Psychology Conference (EAWOP) 2009, which was hosted in Spain, and SIOPSA presentations during 2009 and 2013 in South Africa.

\section{Purpose of the study}

The purpose of the study, which was concluded in 2011, was to explore shifts in work identity experienced by individual research team members during the SANPAD project wherein they studied work identity themselves. This article focuses on aspects within the scope of the SANPAD project plan (SANPAD, 2006) and does not introduce new discussions on the larger debate on positive organisational psychology or positive organisational studies.

\section{Literature review}

Work identity changes in varying degrees, sometimes marginally, in an unhurried and almost unnoticed fashion (Ibarra, 2004). At other times, a need for change in work identity may be a matter of urgency, leading to radical and even abrupt changes. This defines the particular fluid feature of identity, creating the possibility of shifts in work identity (Ibarra, 2004).

\section{Defining work identity}

The SANPAD project team defined work identity as a multiidentity, multifaceted and multilayered construction of the self that shapes the roles in which individuals are involved in the employment context (Lloyd, Roodt \& Odendaal, 2011).

According to Ibarra (2004), work identity consists of finding identification in one's work domain, in other words in what one does, with whom one engages and how one negotiates the dynamics of change.

The following definition of work identity summarises the essence of the concept:

Work identity involves the creation, positioning and identification of oneself within a work context, through determining preferred activities and identifying communities of practice that are relevant to engagement. Work identity is dynamic and fluid, and requires continuous personal scrutiny to determine aspects in make-up that need to be developed to make an impact on a particular work milieu. (Agostino, 2004; Buche, 2006; Du Gay, 1996; Gini, 1998; Ibarra, 2004; Kirpal, 2004; Lloyd et al., 2011; Sveningsson \& Alvesson, 2003; Walsh \& Gordon, 2008)

\section{Contemplating a guiding framework}

Ibarra (2004) provides a useful framework for understanding work identity that focuses on the process of career transitions. A career transition involves a complete change in career and thus a fundamental change in work identity. A shift in work identity, however, involves the negotiation of work identity within a current sphere or profession, ranging from slight changes in perspectives to exploring various types of work.

Ibarra (2004) identifies three important aspects when considering work identity and associated shifts.

\section{Aspect 1: Work identity involves our daily tasks}

Ibarra (2004, p. 18) refers to 'what we do, the professional activities that engage us' and to strategies and tactics that are employed to enable us to survive and reach the desired potential. Chalofsky (2010) highlights the importance of 'the work itself' and refers to the fulfilment of one's purpose through engaging in activities, often for the greater part of one's waking hours. This includes the mastery of work performance, searching for learning, gaining independence and being empowered.

Fox (1994, p. 1) supports this view and further states that 'work touches life itself'. Fox (1994) also focuses on the how, and emphasises that attitude determines how professional activities are approached. Henry David Thoreau said: 'dwell as near as possible to the channel in which your life flows' (Hakim, 2007, p. 125).

\section{Aspect 2: The social and relational component of work identity}

Consistent with the basic assumption that identity is relational, Ibarra (2004, p. 18) refers to the company we keep, our working relationships and the professional groups to which we belong'. Hakim emphasises the importance of collaboration with others and states that 'working with others is the core of this notion', using the migratory behaviour of wild geese as an apt example (Hakim, 1994, p. 100).

The importance of the social dimension is mentioned by Swann, Johnson and Bosson (2009), who state that a sense of 'connectedness' through the establishment and maintenance of social connections is an important function of work. Wheatley (2006, p. 68) refers to the term 'ownership' as: 'the emotional investment of employees in their work'. Chalofsky (2010, p. 142) terms ownership as 'social capital', which refers to the 'connections among individuals, social networks and groupings, within the norms of reciprocity and trustworthiness'. According to Chalofsky (2010, p. 143), organisations are in fact by their very nature 'social institutions'. 
Identity depends on social encounters amongst individuals within a specific social, cultural and ethnic context and purpose. Religion, status, gender, language and other considerations become relevant and serve to determine position in a community (Abma, 1996; Creed \& Scully, 2000; Erikson, 1968; Goffman, 1961; Ibarra, 2004; McAdams, 2003; McAdams, Josselson \& Lieblich, 2006; Rainer, 1997; Smith \& Sparkes, 2008; Van der Ross, 2010).

Relational identity implies that a society determines whether a story of a life is worth telling. If the story (or life) does not resonate with society, identity is not regarded as significant. Stories live or die 'according to a society's implicit understanding of what counts as a tellable story, a tellable life' (McAdams, 2003; see also Beech, 2008; Erikson, 1968; Illeris, 2003, 2004).

\section{Aspect 3: Work identity involves exploring alternative paths}

Ibarra (2004) contends that at times in our working lives, we choose to explore alternative paths. This is often triggered by a defining moment and is made possible by the idea of an individual choosing from a range of 'possible selves' in redefining and re-inventing work identity.

Part of the process of redefining ourselves involves making use of the notion of identity as a story. Stories have selfmaking value as the revisiting and retelling of stories and the negotiation of roles attain congruence or 'fit' in with continually changing circumstances (Ashforth, 2001; Baressi, 2006; Berger, 1963; Bruner, 2003; Fivush \& Buckner, 2003; Ibarra, 2004; Ibarra \& Lineback, 2005; Jones Thomas \& Schwarzbaum, 2011;McAdams, 2003; Raggatt, 2006; Svenningsson \& Alvesson, 2003).

Chalofsky (2010) supports this notion with Maslow's (1971, as cited by Chalofsky, 2010) well-known idea of selfactualisation. He mentions Maslow's research of individuals who transcended self-actualisation and became 'devoted to a task, vocation or calling transcending the dichotomies of work and play' that allowed the expansion of their capabilities of self to 'virtually unlimited potential'. Hakim (2007, p. 19) adds that 'to create your future, you need to become an explorer with the mission of determining what you know and what you don't' (Also see Bridges, 1994, 1997).

Having explored the concept of work identity, the next section will provide some insight with regard to the research design and approach with the focus on the research question: reflections on shifts in work identity of research team members.

\section{Method \\ Research approach}

The research was conducted from a social constructionist perspective and entailed a process of co-constructing identity narratives between participants and the researcher (see Crotty, 1998; Grbich, 2007). The aim was to focus on context-specific factors that influenced the work identity of individual research team members and the meaning attached was shared by the stories told (Flick, 2009; Smith \& Sparkes, 2008).

\section{Research strategy}

Multiple case studies were used, with the focus on the intrinsic case (Yin, 2003). This required an evaluation of each case in terms of its own particular background in order to develop what was perceived to be 'the case's own issues, contexts and interpretations, its thick description' (Stake, 2005, p. 450; also see O'Reilly, 2009).

The purpose of a case study is to analyse the context and the process to illuminate theoretical issues (Hartley, 2006; also see Denscombe, 2003).

The research strategy involved the development of themes from the multiple case studies.

\section{Research design \\ Research setting}

As mentioned previously, the research setting of the study was the SANPAD project team. The focus of this study was the four master's degree students (including the researcher) and two PhD students. During two sessions, two interviews were conducted with each student totalling 10 interviews. The researcher reported shifts in her own work identity by means of an auto-ethnographic account.

\section{Entrée and establishing the researcher's role}

In accordance with the above the researcher of this study formed part of the research team and was also responsible for recording the 'history' and 'lifespan' of the project. Involvement in all endeavours of the research team ensured positive engagement.

\section{Sampling}

The initial idea was to include both the students and their study leaders in the study. One $\mathrm{PhD}$ student withdrew from the project. Given the scope of the topic, the volume of data gathered exceeded the requirements for a master's degree study. Owing to the detailed analysis required by the case study design, a smaller sample was selected by the project manager and the two study leaders of the researcher. This sample included only the six students who had completed their degrees.

\section{Data-collection method}

The topic required an approach that valued detailed descriptions about the setting, context, frame of reference of each participant, explorations of their lived experience and the meaning they attached to their experiences (Marshall \& Rossman, 2006, p. 114; also see Babbie \& Mouton, 2001). Shifts in work identity may be subtle and only involve slight changes in perspectives; however, shifts may be more profound and result in exploring various types of work and 
actual career changes. The brief of the researcher was to report on shifts in the work identity of the participants whilst they were studying work identity themselves.

Interviews and integrating participant observation, given the involvement of the researcher in all the endeavours of the research team, were used to collect data. Semistructured interviews with team members were conducted on two occasions. An interview protocol was used to assist in focusing attention. The first round of interviews involved exploratory discussions relating to personal identity matters, contextual factors and work identity experiences. A second set of interviews were conducted approximately 12 months later to confirm shifts that may have occurred, emerging themes, to investigate unexplored areas and to ensure trustworthiness of the research.

Shifts in work identity were determined throughout the data-gathering process by comparing initial findings with the most recent data gathered in the second interview. Interview data was utilised to craft a story for each participant: storytelling was the strategy used to present the individual case studies. The research participants' stories were embedded in the interview content and narrative analysis could be used for 'crafting a story from the events in the setting ... a way of presenting data' (Bailey, 2007, p. 162). As previously mentioned, the involvement of the researcher in all endeavours of the research team ensured building of rapport with participants and allowed an opportunity for participant observation.

\section{Data analysis}

Thematic analysis formed part of the data analysis. Bailey (2007, p. 158) proposes that 'storytelling incorporates thematic analysis', a process in which researchers meticulously and carefully need to read and reread through transcriptions and other data (Rice \& Ezzy, 1999). Open coding was applied by asking particular questions relating to shifts in the data collected. Repetitive codes were identified by comparing the various interviews and by continuously revisiting the collected data. Bailey (2007, p. 127) argues that 'qualitative researchers actively create the final product that they believe adequately represents their observations and interactions'. Four themes were identified as indicated in the abstract.

\section{Strategies to ensure quality of data}

Peer debriefing and member checking actions were conducted when participants had the opportunity to review and comment on the representation and interpretation of the data gathered (Flick, 2009; Schwandt, 2007).

\section{Reporting}

Reflexivity as a process of self-discovery and personal mastery to determine how beliefs, viewpoints, perceptions and imperfections might influence the study, as well as the reporting, need to be emphasised. Reflexivity informs the reader about the point of departure of the researcher and enables us to determine 'what is known as well as how it is known' (Etherington, 2004, p. 37). In this study the researcher made use of a variety of writing styles.

\section{Findings}

The multiple case study design implies that each participant's work identity needs to be considered contextually as a separate 'case'. The findings will be discussed in two sections: work identity case narratives and themes in work identity shifts. Table 1 provides a summary of the biographical particulars of participants and also sets the context of each of the six participants. It further includes relevant quotes indicating catalysts and realisations that influenced shifts in work identity.

\section{Work identity case narratives}

Each participant derives meaning from different things and is driven by a particular set of values (compass points) informing their reactions to events and influencing shifts in work identity. Shifts in work identity can be plotted on a continuum. On the one end of the continuum, a shift may be profound and may manifest itself in a pronounced change such as a career change or move and on the opposite side a shift may be a nuance only, a subtle alternation.

\section{Participant 1}

Participant 1 regards family and relationships as a critical part of her life and is constantly striving to attain a sense of what she describes as 'equilibrium' between her different identities. In reflecting on her own work identity, triggered by engaging with her master's study, she learned what was important to her and now has an awareness regarding work identity and the dynamics that are at play in an organisational context.

The realisation that her career in Organisation A was not providing a challenge or adequate development opportunities culminated in a shift. Her subsequent move to Organisation B made her realise that an industry can also provide a sense of identity.

Organisation B offered her the opportunity for an internship that is required for registration as an industrial psychologist. She subsequently completed her master's degree and internship which were important on her journey to become a professional industrial psychologist.

The move to Organisation B resulted in a situation where she became disenchanted with the organisational culture.

She experienced a shift from a previous positive experience (Organisation A) and had to find alternative means of identification, which in her case proved to be her work group (Organisation B). She assessed herself and her own competence in terms of that of her work group. The focus on performance enhancement was critical to remain competitive. Thus, her workgroup played an important role in defining her work identity which related to the notion of work identity as relational and multifaceted. 
TABLE 1: Biographical particulars and contextualising participant stories and realisations or catalysts relating to shifts in work identity.

\begin{tabular}{|c|c|c|c|}
\hline Participant & Biographical particulars & Realisations and catalysts & Shifts in work identity \\
\hline \multirow[t]{6}{*}{ Participant 1} & \multirow{6}{*}{$\begin{array}{l}\text { - Married } \\
\text { - Female } \\
\text { - Parent } \\
\text { - } 30-40 \\
\text { - Business solutions } \\
\text { consultant } \\
\text { - Master's degree } \\
\\
\text { student }\end{array}$} & - & Moved from Organisation A to Organisation B. \\
\hline & & $\begin{array}{l}\text { I walked out of the funeral service, and as I was walking back to } \\
\text { my car, I just thought to myself, I cannot die doing this job. }\end{array}$ & Found no meaning in work at Organisation A. \\
\hline & & $\begin{array}{l}\text { That was an interesting thing, how the industry that you work in } \\
\text { provides a sense of identity as well. }\end{array}$ & Found that a particular industry can provide a sense of identity. \\
\hline & & $\begin{array}{l}\text { Contrasted two organisations: 'people-centred' }(A) \text { versus } \\
\text { 'mean-spirited' }(B) \text {. }\end{array}$ & Identification shifted to work group in Organisation B. \\
\hline & & Team identity or group identity can fill in the gaps. & \\
\hline & & $\begin{array}{l}\text { He actually said to me: 'Oh I did not know you were pregnant, } \\
\text { I just thought you were getting fat.' }\end{array}$ & Found that public domain impacted on private domain. \\
\hline \multirow[t]{4}{*}{ Participant 2} & \multirow{4}{*}{$\begin{array}{l}\text { - Single } \\
\text { - Female } \\
\text { - } 30-40 \\
\text { - } \text { HR practitioner } \\
\text { - Master's degree } \\
\text { student }\end{array}$} & $\begin{array}{l}\text { Reached a development 'ceiling' in government sector and } \\
\text { victimised after refusal to commit fraud. Freed from the restraints } \\
\text { of bureaucracy: 'Emancipation of myself'. }\end{array}$ & Moved to semi-state, nature conservation industry. \\
\hline & & $\begin{array}{l}\text { Bored by only receiving a more substantial budget with no new } \\
\text { challenges. }\end{array}$ & $\begin{array}{l}\text { Entrepreneur: Invested in computer training franchise. Emphasis } \\
\text { on 'self' required a shift. She had to direct everything herself. }\end{array}$ \\
\hline & & $\begin{array}{l}\text { Her need to engage in a more secure corporate environment } \\
\text { facilitated her next move. }\end{array}$ & Became HR practitioner in mining industry. \\
\hline & & $\begin{array}{l}\text { Studies and being able to apply learning in work environment } \\
\text { allowed strategic approach. }\end{array}$ & Became a strategic player in her new organisation. \\
\hline \multirow[t]{4}{*}{ Participant 3} & \multirow{4}{*}{$\begin{array}{l}\text { - Single } \\
\text { - Male } \\
\text { - } 20-30 \\
\text { - Academic } \\
\text { - Master's degree } \\
\text { student }\end{array}$} & $\begin{array}{l}\text { Gains from participation in development initiative in his } \\
\text { department. }\end{array}$ & $\begin{array}{l}\text { Comes to terms with his personal identity, his sense of self, } \\
\text { exploring his relationships with colleagues and his purpose in life. }\end{array}$ \\
\hline & & $\begin{array}{l}\text { I identify more with my profession in industrial psychology. ... } \\
\text { I see myself as an educator. }\end{array}$ & $\begin{array}{l}\text { Limited identification with his organisation, only with his } \\
\text { profession. }\end{array}$ \\
\hline & & Internship experience: Disillusioned by lack of transformation. & $\begin{array}{l}\text { Expressed need to be a change agent: 'to change people's view of } \\
\text { how they see people'. }\end{array}$ \\
\hline & & $\begin{array}{l}\text { Review experience: It was horrible. I think that was the first time } \\
\text { I actually questioned whether or not I should be here. }\end{array}$ & $\begin{array}{l}\text { Negative impact on his work identity, given his relationship focus, } \\
\text { impacted upon self-esteem within his work environment. He } \\
\text { regards his work environment currently as 'cold' and 'cut-throat'. }\end{array}$ \\
\hline \multirow[t]{4}{*}{ Participant 4} & \multirow{4}{*}{$\begin{array}{l}\text { - Single } \\
\text { - Female } \\
\text { - } 30-40 \\
\text { - } \text { Academic } \\
\text { - PhD student }\end{array}$} & $\begin{array}{l}\text { I would be too scared to say: I am a ... I would rather say: I am a ... } \\
\text { in training. }\end{array}$ & $\begin{array}{l}\text { She discovered herself and her 'possible selves' within the } \\
\text { research community. }\end{array}$ \\
\hline & & $\begin{array}{l}\text { The development of my understanding of my role in the } \\
\text { 'organisation', that, and all the facets. I got introduced to the } \\
\text { facets. }\end{array}$ & $\begin{array}{l}\text { A new world opened up for her owing to the work identity project. } \\
\text { She realised her career allowed her exposure opportunities, } \\
\text { foreign and local. }\end{array}$ \\
\hline & & $\begin{array}{l}\text { The election of Barack Obama, first Black American president: It } \\
\text { brought a sense of liberation in a way. ... Do not feel inferior; do } \\
\text { not look at the fact that you are a woman. Look at your potential. }\end{array}$ & Making peace with being different. \\
\hline & & $\begin{array}{l}\text { Never put yourself down because you do not have. ... I get angry } \\
\text { with myself. }\end{array}$ & Coming to terms with perception of self. \\
\hline \multirow[t]{3}{*}{ Participant 5} & \multirow{3}{*}{$\begin{array}{l}\text { - Married } \\
\text { - Male } \\
\text { - Parent } \\
\text { - } 50-60 \\
\text { - } \text { Ph business solutions }\end{array}$} & $\begin{array}{l}\text { Dit het ' } n \text { impak definitief. Jy sien ander goed in 'n ander lig. } \\
\text { Blootgestel aan goed wat jy nooit in jou lewe sou nie. ... A 'life- } \\
\text { changing experience' and a 'life dream come true'. }\end{array}$ & $\begin{array}{l}\text { (Involvement in the work identity project broadened his horizons } \\
\text { dramatically.) }\end{array}$ \\
\hline & & His is viewed differently by colleagues and supervisors at work. & $\begin{array}{l}\text { Being acknowledged within his professional environment did play } \\
\text { a role and gave meaning to his study and work endeavours. }\end{array}$ \\
\hline & & He has entered a new social dimension. & $\begin{array}{l}\text { He excels in his new role at work: as advisor, he is expected to find } \\
\text { solutions. }\end{array}$ \\
\hline \multirow[t]{4}{*}{ Participant 6} & \multirow{4}{*}{$\begin{array}{l}\text { - Married } \\
\text { - } \text { Female } \\
\text { - Mother } \\
\text { - } 30-40 \\
\text { - Police officer } \\
\text { - Master's degree } \\
\\
\quad \text { student }\end{array}$} & Personal circumstances required shift to new workplace and city. & Affected a move to a new component within current organisation. \\
\hline & & I did not want to attract unnecessary attention to myself. & 'Perception of self' evaluated. \\
\hline & & $\begin{array}{l}\text { I always thought that becoming a manager would be a natural } \\
\text { progression in my career path. Not anymore! }\end{array}$ & Not an avenue she wanted to explore any longer. \\
\hline & & $\begin{array}{l}\text { On } 01 \text { December } 2011 \text { I would have had } 20 \text { years' service in this } \\
\text { organisation, and I decided that I wanted to do the next } 20 \text { years } \\
\text { of work differently! }\end{array}$ & Actively planning a shift. \\
\hline
\end{tabular}

She needed a mentor to guide her in her development and professional growth and probably in making sense of what she called a 'mean-spirited' organisation. Her shift in this regard emphasised the relational component of work identity, the necessity to engage with colleagues and communities of practice and in establishing networks of people from whom one can benefit. This notion is consistent with the Ibarra (2004, p. 18) framework, which refers to 'the company we keep, our working relationships and the professional groups to which we belong'. This is consistent with the basic assumption of identity as relational.

Afterjoining Organisation B,Participant 1 had toacknowledge that motherhood was accompanied by compromises in terms of career opportunities and possibilities and she had to make a shift in her approach to career options. She adopted a practical approach to her circumstances, she consciously shifted her focus and decided to adopt a philosophical view. Her strategy was to focus on aspects at work that mattered and to diminish the aspects that didn't.

Regarding motherhood, Participant 1 compiled a comprehensive list of requirements for a new environment in order to accommodate personal lifestyle realities and her value system. She realised that her role as mother added a lot of complexity to her work identity and that she could not deal with work in isolation, since other identities impacted on her work identity.

\section{Participant 2}

Participant 2 is restless and focuses on continuous professional development and growth opportunities. This is evident from her deliberate and conscious management of 
her career progression. She finds meaning in her involvement in her spiritual community and draws her strength from that. Throughout the research she experienced several defining moments that acted as catalysts for her subsequent shifts.

Prior to becoming involved in the research project, Participant 2 was subjected to victimisation in her work environment. Disillusionment with the organisation and rank orientation hastened her departure. She was forced to make a mind shift from an environment in which individuals were defined by rank and position to pursue a career in an environment in which she was defined by her profession and competence in a specific area of expertise. She was no longer defined by rank or position. She stated that 'I now define myself'.

She experienced a shift in her work identity and found application value for her studies in her workplace whilst dealing with a corporate retrenchment process.

The death of her mother forced her to lead a more balanced life by working more reasonable hours and allocating time for personal activities. This indicated a shift in taking a deliberate stance on balancing personal identity versus work identity.

In time she reached her peak in the semi-state organisation and became an entrepreneur. In this process, her spiritual focus, as compass point, provided her with an anchor. Having experienced all the facets of being an entrepreneur, she proved to herself that she had become a truly independent being.

Becoming an entrepreneur was the ultimate step in a developmental process. This compelled her to move from a rigid, highly institutionalised context to an entrepreneurial context in which she was able to set her own parameters and largely define her own work identity.

Eventually Participant 2 moved back to the corporate environment owing to the realisation that she had accomplished the ultimate quest in proving her autonomy. Security and greater opportunities prompted her shift to a more secure corporate environment.

\section{Participant 3}

Participant 3 locates meaning in relationships and in building a network amongst colleagues and others.

Participant 3 enjoys opportunities to explore foreign countries and seeks exposure, personally and as a young academic. He strongly identifies with being an industrial psychologist and establishing himself in his career of choice. He has a need to add value and bring 'something back to the organisation'. Participant 3 would also like to establish himself within the research community.

In doing his internship at a large company, he became aware that they were not transforming and were not dealing with affirmative action as they should. The lack of a diversity focus in industry inspired him to utilise his career in becoming a change agent. What he found to be lacking in the industry he wanted to address as part of his postgraduate studies in cross-cultural psychology.

Another defining moment was prompted by Participant 3's panel review, which led him to question whether he had a future in his particular field. A review by peers of his work signified a shift regarding the perception of his role and approach to his vocation, as well as his perception of his colleagues. It forced him to reflect on his career, the organisation and his alignment and associations with colleagues. Given that relationships were important to him, the review experience strongly influenced his work identity.

Participant 3 acknowledged that he did not identify with his organisation, but with his professional identity and that he considered himself to be an educator. He experienced a shift in emphasis from organisational identification to regarding himself as an 'educator'. He located his work identity in this shift.

\section{Participant 4}

Participant 4 finds meaning in being able to account well, not only for her talents, but also for her strong spiritual drive to share and to show 'dividends' in providing guidance to individuals entrusted to her. She derives strength and meaning from her spiritual beliefs that spill over in a drive to share. In her case, development is about sharing all she has learned. She experienced a shift regarding roles to be fulfilled and moved from lecturing to research.

Participant 4 was required to engage and network with foreign counterparts. Being inexperienced, she joined an initiative that equipped individuals to perform the required tasks. She is now able to identify with a profession and consciously identifies role models to emulate. Her approach was evidence of a conscious shift in her work identity and equipped her to fulfil a leadership role.

She experienced an additional shift whilst visiting other countries and coming into contact with other cultures as part of work-related endeavours. This triggered an awareness of others and a shift occurred in the way in which she not only perceived others, but also herself.

Participant 4 acknowledged an internal struggle with being different in a diverse work environment and also has perceptions regarding the image of an 'academic'. Her own perception regarding a professional image now extends to include her unique persona and appearance in her field.

\section{Participant 5}

Participant 5 finds meaning in adding value to the work and personal lives of young professionals. He functions as a committed, loyal employee of his organisation and, as an expert, acts in an advisory capacity. 
In contrast with the much younger team members, Participant 5 reflects on his career and the path he has followed. He is not merely in pursuit of position, but he is an individual who finds meaning by investing time and energy, not only in a work context, but also in engaging with fellow students and researchers.

Participant 5 is excited by the opportunity to make theory practical. That he is regarded as an expert in his field at work provides meaning to him. Prior to completing his doctorate he became aware that colleagues and supervisors were viewing him in a new light, namely that of a trusted advisor. He has entered a new social dimension and experiences this as fulfilling, both in his contact with colleagues and fellow students.

Given his introverted nature, presenting at an international conference posed a challenge to Participant 5. This forced him to explore new territory by addressing the one aspect that was lacking in his armour, namely that of public speaking.

\section{Participant 6}

Whilst all participants have been faced with challenges during the project, Participant 6, the researcher in this particular study, was confronted with the reality of disliking her story of work identity.

Finding meaning in work was important to Participant 6, but her work environment did not provide this satisfaction and her personal circumstances made it undesirable to effect work-related changes. She moved to another city and was transferred within her organisation. She was disillusioned, as the new work environment did not measure up to her expectations. She experienced a profound shift in her work identity from engaging in meaningful training-related tasks to what she regarded as menial, administrative functions. This caused her work identity to shift and to become almost non-existent. She became disengaged, lacked work identification and failed to find identification with her work. She only found purpose and meaning in the context of her family and study endeavours, which guided and anchored her.

In time Participant 6 realised that she was no longer identifying with the organisation and had no wish to be part of the management establishment. She could not relate to the way organisational members were dealing with her and one another. She had to acknowledge that in the long run her work would have no meaning or significance.

Participant 6 experienced a major shift in embarking on her master's degree as this made her dissatisfaction and lack of meaning more pronounced. She was constantly confronted with other participants' stories, literature and study leaders, which resulted in immense discomfort and incongruence. Participant 6 became an example of a disintegrated individual work identity, being the result of a work life that lacked meaning and purpose.

\section{Themes}

\section{Theme 1: Compass points guiding our journey}

The ability to engage with a meaningful task on a daily basis is critical to work identity. This theme focuses on aspects that provide meaning and hope in life. The term 'compass points' relates to aspects that are central to providing direction, purpose and meaning in the lives of participants. Additionally, compass points are central in triggering shifts in work identity and the constant search for meaningful work and life. Whatever form this may take, it leads to negotiating aspects of work identity which in turn leads to shifts. Defining moments occur when life circumstances are negotiated. Defining moments can trigger a shift in work identity.

The contextual reality of the participants proved critical in this study, as this determined their individual meaning.

The search for meaning is ongoing and appears to be influenced by life and career stage. Life and career stage involves the testing and finding of a viable work identity, searching for role models to guide career development and progression or finding whether a participants may be in a position to assist others based on their own experience.

Should an individual find no meaning in their work (Participant 6), disintegration of the person's work identity may ensue. In such cases the focus on other meaningful facets, such as family, personal relationships, study endeavours and hobbies, may be vital. Constant reflection regarding meaning is essential. This will result in a balanced perspective and sound decision-making skills.

\section{Theme 2: Navigating life circumstances}

This theme refers to the contextual realities within which work identity is negotiated. Work identity is in a constant relationship with other facets of identity. 'Navigating' implies searching for the best possible route to follow.

In negotiating work identity, we are confronted with personal, social and career choices, which determine the type of demands we have to negotiate whilst working. The theme on navigating life circumstances focuses on how participants deal with demands associated with work roles, accommodating children and family, personal roles, the importance of support systems and coping strategies and compromises required in negotiating work identity.

A significant contextual factor influencing work identity is motherhood as an aspect of personal identity. Two of the participants in the study are mothers and both highlighted this contextual factor as critical in negotiating work identity. Owing to their motherhood they were willing to make compromises regarding career options and progression, opting for shifts in work identity. Additionally, attempting to balance personal and work identity required a sound support system. Life circumstances thus served as a constraining 
factor in terms of possible shifts. The ability of an individual to engage in change is dependent on the perception of contextual factors.

\section{Theme 3: Negotiating identity and identification in the workplace}

This theme signifies where and with whom the individual identifies. Work identity refers to certain aspects of identification and various aspects of identification emerged. These were the job, peer groups, the organisational culture, broader identifications such as professional identity, that of 'the educator' and the entrepreneur. Where one aspect of identification was lacking, shifts were made to alternative foci of identification.

In the case of Participant 2, alternative foci of identification were a very individualistic approach, not allowing the organisation to 'claim' her.

In the case of Participant 3, alternative identification resulted in anchoring himself within his chosen profession, that of an industrial psychologist and 'an educator'.

Participant 1 located her work identity (in Organisation A) within the organisational culture, even though the work was not meaningful. In Organisation B, she struggled to identify with the culture and shifted her identification to her profession as industrial psychologist, the industry within which she worked and her work group.

Participant 4 experienced a subtle shift in work identity, initially identifying with some aspects of her roles associated with her field, but has been exposed to the many facets of her profession and has begun to identify with these facets.

As indicated, work identity is a social phenomenon. The negotiation of work identity is done in consultation with others and implies a process of collaboration.

It may well be that the implication for work identity is that participants assess themselves by making comparisons, as in the case of Participant 1 and Participant 3. A positive comparison will act as a motivator and a negative comparison may be demotivating or become an area that requires further development.

In dealing with their respective work environments, young professionals need to find strategies that work for them. In executing a shift, young professionals should be aware that they may find themselves in a new position or in a state of isolation.

Young professionals expressed the need to have access to a dynamic system of knowledge management and contact with experienced professionals who are capable of sharing and transferring competence in certain areas. Participant 1 mentioned the need for professional role models and Participant 3 and Participant 4 highlighted the positive impact of development initiatives in their work environment in their own development of work identity. That Participant 5 's guidance and support of younger colleagues has been met with a positive response is also testimony to its importance.

\section{Theme 4: Perception of self}

This particular theme focuses on the perception of self within a work context and its implications for work identity.

In the context of the study, perception of self involved a specific representation of oneself, in order to establish and maintain a particular image.

In terms of this particular theme this study involves an extension of the Ibarra (2004, p. 60) notion of 'trying on new identities' to include 'trying on new images and looks' as a performance within a workplace and the significance of that for an individual work identity.

For some participants 'perception of self' appeared to be related to own perceptions of professionalism. Personal appearance adds an additional dimension to who I am at work and what I do. This includes not only how I do what I do, but also how I look and the perception others form of me when I do what I do. An academic and a consultant may consciously adopt different identities to portray a specific image to add new dimensions to their work identity.

Personal perceptions appear to inform behavioural patterns regarding individual attempts to be assimilated into a work situation, in portraying personal perceptions of what will be an acceptable image and to be seen as being professional.

\section{Discussion Outline of the findings}

In reflecting on the above-mentioned themes the researcher and her study leaders identified relationships amongst the themes.

\section{Theme 1: Compass points guiding our journey}

The stories of participants suggest the critical importance of finding meaning and purpose in the professional activities they are engaged in. This is consistent with the work of Chalofsky (2010), who highlights the importance of fulfilling one's purpose through the work one does. Whilst signature strengths refer to both 'character traits and values most central to who we are', the compass points in this study, seemed to resemble the 'value' or 'virtue' component of signature strengths (Ulrich \& Ulrich, 2010). Where participants no longer find meaning in what they do, there is a process of dis-identification, one likened to identity malaise highlighted by Sveningsson and Alvesson (2003).

\section{Theme 2: Navigating life circumstances}

The stories of participants suggest that contextual realities play an important role in how they negotiate life and work. 
These realities differ from participant to participant. Ibarra (2004) emphasises the significant role of contextual realities and the way in which individuals approach the possibility of shifts. In the case of our participants, context proved relevant in that participants had to negotiate a variety of contextspecific challenges on which they based their decisions to execute shifts or not.

Ibarra (2004) makes reference to defining moments; these were experienced to a greater and lesser degree by all participants. Defining moments, catalysts and significant contextual factors contributed towards a required shift in work identity amongst the participants.

In the cases of Participant 1 and Participant 6, catalysts were experienced that suggested that a shift was required. However, when executing the shift they did not anticipate negative consequences. This suggests that Ibarra's (2004) advice, to be cautious and to explore whether personal preferences, competencies and values are aligned with those of the new organisation prior to engaging with a new work environment, is sound. Otherwise one would have to tolerate the outcome of a decision that may be ill-informed.

Work identity can never be considered in isolation, as personal life circumstances play a role in facilitating or constraining the negotiation of work identity.

\section{Theme 3: Negotiating identity and identification in the workplace}

None of the participants experienced radical career transitions. The flexibility of the work identity concept as highlighted by Ibarra (2004) was clearly evident. Individual emphasis on various facets of work identity (or identification) at various times is dependent on contextual factors. This is consistent with Ibarra (2004), as she highlights the importance of context in understanding career transitions (for our purpose shifts). The shifts are determined by the meaning and purpose various aspects of work provide (Theme 1) and are impacted by the navigation of life circumstances (Theme 2). This facet of a shift is similar to Ibarra's (2004) notion of engaging with new peer groups, contacts and role models to explore various aspects of the self in order to make a transition. It is the fluidity of work identity that enables these shifts at various times and enables people to grow and develop within their chosen work identity. With this in mind, the importance of mentorship in the development of work identity was also confirmed.

Participants 1, 2 and 4 are more or less of the same age (30-40) and are in the process of establishing themselves in their respective careers with the view of reaching their potential. All of them expressed the need for a mentor or coach. Participant 3 (25-30) and Participant 6 (30-40) are disengaged and need to craft work identities that are congruent with who they are. In contrast to the other participants, Participant $5(50+)$ is at ease with himself and those around him within his work identity. This is consistent with his life and career stage in his capacity as an expert. He is still willing to explore possible selves in order to extend his repertoire of skills.

\section{Theme 4: Perception of self}

For purposes of this study, Ibarra's (2004, p. 60) notion of 'trying on new identities' includes 'trying on new images and looks' as work identity entails an element of performance. In this study, irrespective of their life and career stage, all participants were engaged in processing possible selves. Engaging in such a process is consistent with the notion of identity and work identity as fluid and with Ibarra's (2004, p. 19) portrayal of work identity as a 'lifelong process of questioning and affirming the relationship between who we are and what we do'. Ibarra's (2004, p. 87) observation that 'our customary mind-set about who we are and what others expect undermines us in myriad subtle ways' was evident in this study. Participants 1, 4 and 6 were confronted with their own perceptions in terms of their physical appearance in a work context as opposed to how they might be viewed by others. These participants experienced tension regarding the presentation of self which undermined their sense of self prior to coming to terms with these perceptions. In this article, irrespective of their life and career stages, all participants were engaged in processing possible selves. Engaging in such a process is consistent with Ibarra's (2004, p. 19) portrayal of working identity as a 'lifelong process of questioning and affirming the relationship between who we are and what we do'.

\section{Practical implications of the study}

The study emphasised the need experienced by individuals to engage with meaningful tasks on a daily basis. Human resource (HR) professionals need to engage with employees on a continuous basis to determine what provides them with meaning. This will ensure retention of employees and result in the design of appropriate strategies towards this objective.

The study highlighted factors relating to identification within an organisation which in turn will impact on turnover intentions of employees. Employees need to feel valued and experience a sense of identification. HR professionals must engage with employees to determine how to craft strategies that enhance and optimise the value of employees.

The study contributes towards emphasising the necessity of accommodating contextual realities of employees. It highlighted that a natural phenomenon like pregnancy in the workplace needs to be addressed by employers.

An important finding is the acute need of young professionals for adequate role models. It is suggested that HR professionals implement effective mentorship programmes.

This study indicated that young professionals aspire to grow and fulfil professional requirements. Creating internship opportunities within an organisation and treating internship candidates well and in a professional manner may well be a mechanism to attract and retain talent. 
A final contribution of the article lies in acknowledging the impact that a range of contextual factors can have on shifts in work identity.

The study furthermore confirms that Ibarra's (2004) framework is suitable to apply. Her approach, despite being focused on career transitions, also provides a suitable framework for considering shifts in work identity.

\section{Limitations, recommendations and future research}

A conventional research process was not followed, since the researcher only joined the research team 7 months after the study had commenced, to replace two students who had to withdraw from the project owing to personal circumstances. Being a novice researcher, despite the guidance of two study leaders, a process of trial and error in some instances prevailed.

The two study leaders were familiar with the participants. This posed its own challenges since both supervisors had insight into the dynamism of the institution and had personal perceptions regarding these participants.

An additional 10 interviews that were conducted with the more experienced study leaders and one student who withdrew from the project were not used owing to the detailed analysis required by the case study design. It would have been insightful to have included the data supplied by the older study leaders. The issues and challenges of the younger research team members predominated and influenced the nature of the themes that were generated.

The following topics may present interesting possibilities for future research directions:

- The impact of ethnicity and affirmative action within a workplace may be explored and how that relates to negotiating shifts in work identity.

- The relationship between the work identity of professional or white-collar occupations in relation to blue-collar or technical occupations.

- A survey may be conducted where the researcher provides a calendar or diary (timeline follow back), in which respondents record how often they contemplate career moves over a specified period, note triggering events and attempt to record the intensity of considering moves (Belli, Stafford \& Alvin, 2009).

\section{Conclusion}

In contextualising the stories of the participants, it became evident that a story of a life is not static. Fluidity became evident in the way in which those who needed to execute a shift tended to 'hover' in a holding space for a while, until they were able to make the actual shift. In this holding space, where the person yearned for professional fulfilment, they relied on hope to keep the possibility alive.
Dealing with work identity proved to be an ongoing negotiation. The discussion attempted to provide an interpretation that would undoubtedly have changed over time as new experiences and realities intersected the pathways and journeys of the participants.

\section{Acknowledgements}

The research reported in this article is the product of a collaborative research project between the University of Johannesburg and the Vrije University, Amsterdam. Financial support from SANPAD for conducting this research is hereby acknowledged. Conclusions drawn or opinions expressed in this article are those of the authors and do not necessarily reflect the views of SANPAD.

The first author further acknowledges Professor Gert Roodt for providing the opportunity and privilege to be part of the SANPAD project, Dr Anne Crafford and Professor Willem Schurink for exceptional guidance during the research process and Dr Adri Uys for her invaluable guidance and support in completing this article.

\section{Competing interests}

The authors declare that they have no financial or personal relationships that may have inappropriately influenced them in writing this article.

\section{Authors' contributions}

R.A.S. (University of Johannesburg) conducted the research and wrote the manuscript. A.C. (University of Johannesburg) acted as primary study leader and made substantive intellectual contributions to the study. W.J.S. (University of Johannesburg) acted a secondary study leader and made substantive intellectual contributions to the study.

\section{References}

Abma, T. (1996). Powerful stories - The role of stories in sustaining and transforming professional practice within a mental hospital. In R. Josselson \& A. Lieblich (Eds.), Making meaning of narratives, Vol. 6 (pp. 169-193). Thousand Oaks, CA: Sage.

Agostino, J. (2004). Workplace identity. Doctor of Business Administration dissertation. Victoria, Australia: Swinburne University of Technology.

Ashforth, B.E. (2001). Role transitions in organizational life: An identity-based perspective. Mahwah, NJ: Lawrence Erlbaum Publishers.

Babbie, E.R., \& Mouton, J. (2001). The practice of social research. Oxford, UK: Oxford University Press.

Bailey, C. (2007). A guide to qualitative field research. (2nd edn.). Thousand Oaks, CA: Pine Forge Press. http://dx.doi.org/10.4135/9781412983204

Baressi, J. (2006). The identities of Malcolm X. In D.P. McAdams, R. Josselson, \& A. Lieblich (Eds.), Identity and story-creating self in narrative (pp. 201-220). Washington, DC American Psychological Association. http://dx.doi.org/10.1037/11414-009

Beech, N. (2008). On the nature of dialogic identity work. Organization Articles, 15(1), 51-74. http://dx.doi.org/10.1177/1350508407084485

Belli, R.F., Stafford, F.P., \& Alwin, D.F. (2009). Calender and time diary-methods in life course research. Thousand Oaks, CA: Sage.

Berger, P.L. (1963). Invitation to sociology: A humanistic perspective. Garden City, NY: Anchor.

Bridges, W. (1994). Jobshift. How to prosper in a workplace without jobs. London, UK: Nicholas Brealey Publishing.

Bridges, W. (1997). Creating you \& co. be the boss of your own career. London, UK: Nicholas Brealey Publishing.

Bruner, J. (2003). Self-making narratives. In R. Fivush \& C.A. Haden (Eds.), Autobiographical memory and the construction of a narrative self (pp. 209-223). London, UK: Lawrence Erkbaum Associates, Publishers. 
Buche, M. (2006). Gender and IT professionals work identity. Houghton, MI: Michigan Technological University. http://dx.doi.org/10.4018/978-1-59140-815-4.ch068

Chalofsky, N.E. (2010). Meaningful workplaces - Reframing how and where we work San Francisco, CA: Jossey - Bass.

Creed, W.E., \& Scully, M.A. (2000). Songs of ourselves: Employees' deployment of social identity in workplace encounters. Journal of Management Inquiry, 9(4), 391-412. http://dx.doi.org/10.1177/105649260000900410

Crotty, M. (1998). The foundations of social research-Meaning and perspective in the research process. Los Angeles, CA: Sage.

Denscombe, M. (2003). The good research guide for small scale research projects. (2nd edn.). Maidenhead, UK: Open University Press.

Du Gay, P. (1996). Organising identity: Entrepreneurial governance and public management. In S. Hall \& P. du Gay (Eds.), Questions of cultural identity (pp. 151169). London, UK: Sage.

Erikson, E. (1968). Identity - Youth and crisis. London, UK: Faber \& Faber.

Etherington, K. (2004). Becoming a reflexive researcher - Using ourselves in research. London, UK: Jessica Kingsley Publishers.

Fivush, R., \& Buckner, J.P. (2003). Creating gender and identity through autobiographical narratives. In R. Fivush \& C.A. Haden (Eds.), Autobiographical memory and the construction of a narrative self (pp. 149-164). London, UK: Lawrence Erlbaum Publishers.

Flick, U. (2009). An introduction to qualitative research. (4th edn.). London, UK: Sage.

Fox, M. (1994). The reinvention of work - A new vision of livelihood for our time. San Francisco, CA: Harper.

Gini, A. (1998). Work, identity and self: How we are formed by the work we do. Journa of Business Ethics, 17(7), 707-714. http://dx.doi.org/10.1023/A:1017967009252

Goffman, E. (1961). Encounters. Indianapolis, IN: Bobbs-Merrill.

Grbich, C. (2007). Qualitative data analysis - An introduction. Thousand Oaks, CA Sage.

Hakim, C. (1994). We are all self-employed - The new social contract for working in a changed world. San Francisco, CA: Berrett - Koehler Publishers.

Hakim, C. (2007). Rethinking work - Are you ready to take charge? Mountain View, CA: Davies-Black Publishing.

Hartley, J. (2006). Case study research. In C. Cassell \& G. Symon (Eds.), Essential guide to qualitative methods in organisational research (pp. 323-333). Thousand Oaks, CA: Sage.

Ibarra, H. (2004). Working identity - Unconventional strategies for reinventing your career. Boston, MA: Harvard Business School Press.

Ibarra, H., \& Lineback, K. (2005). What's your story? Harvard Business Review, January, 65-71.

Illeris, K. (2003). Learning, identity and self-orientation in youth. Youth-NordicJournalof Youth Research, 11(4), 357-376. http://dx.doi.org/10.1177/11033088030114004

Illeris, K. (2004). A model for learning in working life. The Journal of Workplace Learning, 16(8), 431-441. http://dx.doi.org/10.1108/13665620410566405

Jones Thomas, A., \& Schwarzbaum, S.E. (2011). Culture and identity - Life stories for counsellors and therapists. Los Angeles, CA: Sage.
Kirpal, S. (2004). Researching work identities in a European context. Career Development International, 9(3), 199-221. http://dx.doi.org/10.1108/13620430410535823

Lloyd, S., Roodt, G., \& Odendaal, A. (2011). Critical elements in defining work-based identity in a post-apartheid South Africa. South African Journal of Industria Psychology/SA Tydskrif vir Bedryfsielkunde, 37, 2-15. http://dx.doi.org/10.4102/ sajip.v37i1.894

Marshall, C., \& Rossmann, G.B. (2006). Designing qualitative research. (4th edn.). Thousand Oaks, CA: Sage.

McAdams, D.P. (2003). Identity and the life story. In R. Fivush \& C.A. Haden (Eds.), Autobiographical memory and the construction of a narrative self (pp. 187-202). London, UK: Lawrence Erlbaum Publishers.

McAdams, D.P., Josselson, R., \& Lieblich, A. (2006). Introduction. In D.P. McAdams, R. Josselson, \& A. Lieblich (Eds.), Identity and story - Creating self in narrative (pp. 3-9). Washington, DC: American Psychological Association. http://dx.doi. org/10.1037/11414-000

O’Reilly, K. (2009). Key concepts in ethnography. Los Angeles, CA: Sage Publications. http://dx.doi.org/10.4135/9781446268308

Raggatt, P. (2006). Multiplicity and conflict in the dialogical self: A life-narrative approach. In D.P. McAdams, R. Josselson, \& A. Lieblich (Eds.), Identity and story - Creating self in narrative (pp. 15-33). Washington, DC: American Psychological Association. http://dx.doi.org/10.1037/11414-001

Rainer, T. (1997). Your life as story. New York: Penguin Putnam.

Rice, P., \& Ezzy, D. (1999). Qualitative research methods. South Melbourne, Australia: Oxford University Press.

SANPAD. (2006). Project plan. Johannesburg, South Africa: University of Johannesburg.

Schwandt, T. (2007). The Sage dictionary of qualitative inquiry. (3rd edn.). Thousand Oaks, CA: Sage.

Smith, B., \& Sparkes, A.C. (2008). Contrasting perspectives on narrating selves and identities: An invitation to dialogue. Qualitative Research, 8(1), 5-35. http:// dx.doi.org/10.1177/1468794107085221

Stake, R. (2005). Qualitative case study. In N.K. Denzin \& Y.S. Lincoln (Eds.), Handbook of qualitative research (pp. 443-466). Thousand Oaks, CA: Sage.

Sveningsson, S., \& Alvesson, M. (2003). Managing managerial identities: Organisational fragmentation, discourse and identity struggle. Human Relations, 56(10), 11631193. http://dx.doi.org/10.1177/00187267035610001

Swann, W.B., Johnson, R.E., \& Bosson, J.K. (2009). Identity negotiation at work Research in Organisational Behavior, 29, 81-109. http://dx.doi.org/10.1016/j. Research in Organi
riob.2009.06.005

Ulrich, W., \&. Ulrich, D. (2010). The why of work. New York: McGraw-Hill.

Van der Ross, R. (2010). A blow to the hoop - The story of my life and times. Newlands, South Africa: Ampersand Press.

Walsh, K., \& Gordon, J.R. (2008). Creating an individual work identity. Human Resource Management Review, 18, 46-61. http://dx.doi.org/10.1016/j.hrmr.2007.09.001

Wheatley, M. (2006). Leadership and the new science-Discovering order in a chaotic world. (3rd edn.). San Francisco, CA: Berrett-Koehler Publishers.

Wolcott, H. (2005). The art of fieldwork. (2nd edn.). Walnut Creek, CA: Altamira.

Yin, R. (2003). Applications of case study research. (2nd edn.). Thousand Oaks, CA: Sage. 


\section{Appendix 1: Research ethics}

At the commencement of this study the research team was briefed by the project manager Prof. Gert Roodt in terms of this particular research as a special building block within the broader SANPAD project. By implication, the research team members had no choice but to participate and the normal written permission process was not followed. None of the research participants voiced their opposition or concern at the time or during the interviews.

It was an advantage that the research participants conducted interviews at the manufacturing company and were conversant with the procedures involved, including the use of audio recording devices.

Transparency ensued in the course of the study and a balance had to be maintained between the needs of research participants and information required by the researcher to complete the study. Building rapport with participants most certainly aligned with the Wolcott (2005) concept of this process as one of the 'darker arts' of participant observation.

As previously mentioned, peer debriefing and member checking actions were conducted when participants had the opportunity to review and comment on the representation and interpretation of the data gathered (Flick, 2009; Schwandt, 2007). 